\title{
PENERAPAN MODEL PROBLEM BASED LEARNING UNTUK MENINGKATKAN KEMAMPUAN ARGUMENTASI MATEMATIKA PESERTA DIDIK KELAS X SMAN 2 KOTA JAMBI
}

\author{
Junaini $^{1}$, M. Rusdi ${ }^{2}$, Muslim $^{3}$ \\ Program Studi Magister Pendidikan Matematika, Universitas Jambi, Kota Jambi, Indonesia ${ }^{1,2,3}$ \\ E-mail: junaini_55@yahoo.com
}

\begin{abstract}
ABSTRAK
Penelitian ini dilatarbelakangi oleh fakta bahwa dalam proses pembelajaran matematika di SMAN 2 Kota Jambi, kurang melatih kemampuan argumentasi dan aktivitas peserta didik selama proses pembelajaran. Penelitian ini bertujuan untuk: 1) Mengetahui tindakan pembelajaran guru dalam menerapkan model Problem Based Learning (PBL) dapat meningkatkan kemampuan arumentasi matematika peserta didik, 2) Mengetahui tindakan belajar peserta didik dalam mengikuti pembelajaran model PBL untuk meningkatkan kemampuan argumentasi matematika, 3) Mengetahui lingkungan belajar yang seharusnya diciptakan agar penerapan model PBL dapat meningkatkan kemampuan argumentasi matematika peserta didik kelas X SMAN 2 Kota Jambi pada materi Nilai Mutlak, SPLTV, pertidaksamaan rasional, pertidaksamaan irasional dan SPLDV. Jenis penelitian ini adalah penelitian tindakan kelas yang mengacu pada model John Elliot dan terdiri dari empat tahap; perencanaan (Planning), tindakan (action), pengamatan (observing), dan refleksi (Reflecting). Metode penelitiannya adalah metode kualitatif yang bersifat deskriptif. Penelitian ini terdiri dari tiga siklus, masing-masing siklus terdiri dari tiga kali pertemuan. Intrumen penelitian yang digunakan adalah lembar observasi dan dokumentasi. Hasil penelitian menunjukkan bahwa: 1) tindakan pembelajaran yang dilakukan guru dan tindakan belajar peserta didik dalam model PBL untuk meningkatkan kemampuan argumentasi matematika peserta didik, memiliki tahapan yaitu; mengorientasi peserta didik pada masalah, mengorganisasikan peserta didik untuk belajar, membimbing penyelidikan mandiri dan kelompok, mengembangkan dan menyajikan hasil karya serta menganalisis dan mengevaluasi proses pemecahan masalah, 2) lingkungan belajar yang seharusnya diciptakan agar penerapan model PBL dapat meningkatkan kemampuan argumentasi matematika peserta didik adalah lingkungan belajar sosiol-psikologis yang menimbulkan suasana pembelajaran yang aman, nyaman, dan menyenangkan.
\end{abstract}

Kata kunci: Kemampuan Argumentasi, Model PBL.

\begin{abstract}
This research is motivated by the fact that in the process of learning mathematics at SMAN 2 Kota Jambi, it is not enough to train the students' argumentation and activity skills during the learning process. This study aims to: 1) Know the teacher's learning actions in applying the Problem Based Learning (PBL) model to improve students' mathematical mathematical ability, 2) Know the student's learning actions in following PBL model learning to improve their mathematical argumentation abilities, 3) Know the environment learning that should have been created so that the application of the PBL model can improve the mathematical argumentation ability of class $X$ students of SMAN 2 Kota Jambi on the material Absolute Value, SPLTV, rational inequality, irrational inequality and SPLDV. This type of research is classroom action research that refers to the John Elliot model and consists of four stages; planning (Planning), action (action), observation (observing), and reflection (Reflecting). The research method is a descriptive qualitative method. This study consisted of three cycles, each cycle consisting of three meetings. The research instruments used were observation sheets and documentation. The results showed that: 1) the learning actions taken by the teacher and the learning actions of students in the PBL model to improve students' mathematical argumentation abilities, had stages namely; orienting students to problems, organizing students to learn, guiding independent and group investigations, developing and presenting their work and analyzing and evaluating problem solving processes, 2) learning environments that should be created so that the application of PBL models can improve students' mathematical argumentation abilities are sociol-psychological learning environment that creates an atmosphere of learning that is safe, comfortable, and fun.
\end{abstract}

Keywords: Argumentation Capability, PBL Model. 


\section{PENDAHULUAN}

Berdasarkan Undang-Undang No. 20 tahun 2003 tentang Sistem Pendidikan Nasional pasal 1 ayat 1 menyatakan bahwa pendidikan adalah usaha sadar dan terencana untuk mewujudkan suasana belajar dan proses pembelajaran agar peserta didik secara aktif mengembangkan potensi dirinya untuk memiliki kekuatan spiritual keagamaan, pengendalian diri, kecerdasan, akhlak mulia, serta keterampilam yang diperlukan dirinya, masyarakat, bangsa dan negara.

Upaya untuk memperbaiki proses pembelajaran dapat dilakukan dengan cara memilih metode, pendekatan atau model yang tepat untuk meningkatkan potensi tersebut. Menurut (Jayawardana, 2015) salah satu model pembelajaran yang mampu menciptakan pembelajaran bermakna, dimana peserta didik dapat memecahkan masalah yang dihadapi dan menerapkannya dalam kehidupan nyata, dapat mengembangkan hubungan interpersonal dalam bekerja kelompok serta dapat meningkatkan kemampuan argumentasi adalah Model pembelajaran Problem Based Learning yang selanjutnya disingkat PBL. Model PBL yaitu proses pembelajaran berbasis masalah dimana peserta didik dihadapkan oleh permasalahan yang menuntut mereka untuk aktif dalam proses pembelajaran.

Setiap peserta didik akan mengamati dan memecahkan masalah berdasarkan sudut pandang mereka. Perbedaan cara menyelesaikan masalah antar peserta didik akan memunculkan sikap untuk saling mempertahankan argumen dengan berbagai cara, seperti cara peserta didik mengumpulkan bukti dan fakta yang ada untuk memecahkan masalahnya. Cara peserta didik tersebut akan saling mempengaruhi satu sama lain .

Berdasarkan hasil observasi pada proses pembelajaran dan wawancara terhadap guru mata pelajaran Matematika di SMA Negeri 2 Kota Jambi, diketahui bahwa dalam proses pembelajaran masih berpusat pada guru. Guru dalam memulai proses pembelajaran tidak mengorientasikan peserta didik pada masalah yang autentik dan bermakna bagi peserta didik. Guru kurang memperhatikan kemampuan argumentasi peserta didik. Peserta didik juga tidak dibiasakan untuk memecahkan permasalahan dan menyampaikan pendapat mereka dalam proses pembelajaran. Berdasarkan informasi yang diperoleh melalui wawancara dengan beberapa peserta didik, diketahui bahwa motivasi belajar matematika peserta didik kurang baik. Peserta didik hanya duduk memperhatikan guru berbicara dan mengerjakan soal, sehingga dapat dikatakan kemampuan argumentasi peserta didik kurang berkembang. Semua hal ini tentulah berdampak pada rendahnya kualitas pembelajaran.

Berdasarkan latar belakang tersebut, maka perlu dilakukan penelitian dengan judul Penerapan Model Problem Based Leraning untuk Meningkatkan Kemampuan Argumentasi Matematika Peserta Didik Kelas X SMAN 2 Kota Jambi. Penelitian ini bertujuan untuk 1) Mengetahui tindakan pembelajaran guru dalam menerapkan model Problem Based Learning (PBL) dapat meningkatkan kemampuan arumentasi matematika peserta didik, 2) Mengetahui tindakan belajar peserta didik dalam mengikuti pembelajaran model PBL untuk meningkatkan kemampuan argumentasi matematika, 3) Mengetahui lingkungan belajar yang seharusnya diciptakan agar penerapan model PBL dapat meningkatkan kemampuan argumentasi matematika peserta didik kelas X SMAN 2 Kota Jambi pada materi Nilai Mutlak, SPLTV, pertidaksamaan rasional, pertidaksamaan irasional dan SPLDV.

\section{METODE PENELITIAN}

Penelitian yang dilaksanakan peneliti adalah Penelitian Tindakan Kelas (PTK). Menurut Elliot yang dimaksud dengan PTK ialah kajian tentang situasi sosial dengan maksud untuk meningkatkan kualitas tindakan di dalamnya. Seluruh prosesnya, telaah, diagnosis, perencanaan, pelaksanaan, pemantauan, dan pengaruh dapat menciptakan hubungan yang diperlukan antara evaluasi diri dari pengembangan propesional (Elliot,1991:123). PTK dilakukan oleh guru karena mengalami beberapa permasalahan dalam proses pembelajaran. Dengan demikian, tujuan dilaksanakannya PTK adalah untuk memecahkan permasalahan dalam proses 


\section{$\pi$ (Phi)}

pembelajaran baik dari segi sistem, proses, isi, kompetensi ataupun situasi.

Metode penelitian yang digunakan adalah metode penelitian kualitatif yang penelitiannya dilakukan pada kondisi yang alamiyah. Instrumen dalam penelitian adalah orang atau dalam hal ini adalah peserta didik. Penelitian ini bersifat deskriptif yaitu data yang terkumpul adalah berbentuk kata-kata atau deskripsi (Sugiono, 2013:7).

Penelitian ini dimulai dari fase refleksi awal setelah proses pembelajaran. Studi awal dalam merumuskan masalah penelitian dan selanjutnya baru dibuat perencanaan PTK. Jenis penelitian yang digunakan peneliti mengecu pada model alur PTK John Elliot yang tampak lebih detail dan rinci. Dikatakan demikian karena di dalam setiap siklus dimungkinkan terdiri dari beberapa tindakan yaitu 3 sampai 5 tindakan. Sementara itu, setiap aksi kemungkinan terdiri dari beberapa langkah, yang terealisasi dalam bentuk kegiatan belajar-mengajar. Maksud disusunnya secara terinci pada PTK model John Elliot ini, supaya terdapat kelancaran yang lebih tinggi antara taraf-taraf di dalam pelaksanaan proses belajar-mengajar. Selanjutnya dijelaskan pula olehnya bahwa terincinya setiap tindakan sehingga menjadi beberapa langkah oleh karena suatu pelajaran terdiri dari beberapa sub pokok bahasan atau materi pelajaran. Di dalam kenyataan praktik lapangan setiap pokok bahasan biasanya tidak akan dapat diselesaikan dalam satu langkah, tetapi akan diselesaikan dalam beberapa rupa itulah yang menyebabkan Elliot menyusun model PTK berbeda secara skematis kedua model sebelumnya, yaitu seperti gambar berikut ini.

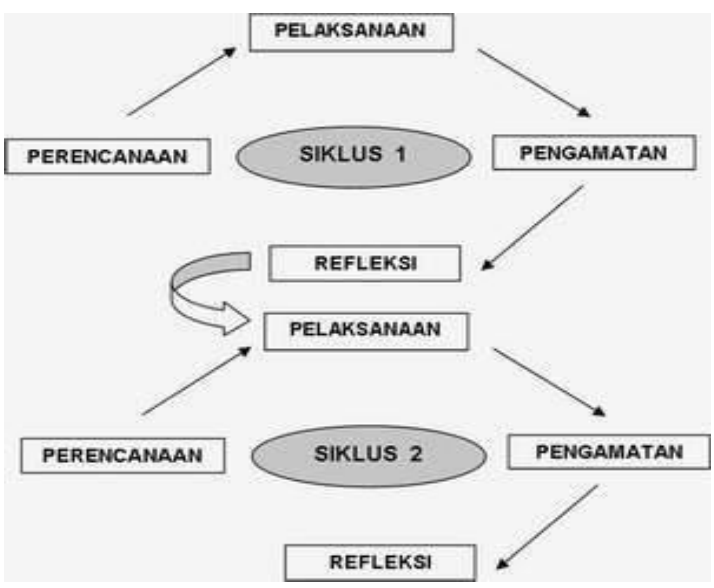

Gambar 1: Diagram Alur PTK model John Elliot

Siklus pada penelitian ini terdiri atas,

1) Perencanaan tindakan (Plan), 2) Pelaksanaan tindakan (action), 3) pengamatan (observation), dan 4) Refleksi (reflection).

Metode pengumpulan data dalam penelitian tindakan kelas ini melalui catatan lapangan, lembar observasi, dan dokumentasi.

Untuk mencapai tujuan penelitian tindakan kelas ini, yakni mengetahui bagaimana penerapan model pembelajaran berbasis masalah dalam meningkatkan kemampuan argumentasi peserta didik di SMAN 2 Kota Jambi dalam pembelajaran matematika, beberapa instrumen penelitian yang digunakan untuk menjawab pertanyaan pada penelitian ini. Data yang digunakan pada penelitian ini adalah :

1. Data tindakan guru dalam menerapkan model PBL akan diperoleh melalui observasi yang dilakukan oleh observer yaitu teman sejawat pada mata pelajaran matematika.

2. Data tindakan peserta didik dalam proses pembelajaran untuk meningkatkan kemampuan argumentasi diperoleh melalui observer yaitu teman sejawat pada mata pelajaran matematika.

3. Data hasil observasi lingkungan belajar peserta didik yang seharusnya diciptakan agar penerapan model PBL dapat meningkatkan argumentasi diperoleh melalui observasi yang dilakukan oleh 


\section{$\pi$ (Phi)}

observer yaitu teman sejawat pada mata pelajaran matematika.

4. Data hasil observasi kemampuan argumentasi matematika peserta didik dalam penerapan model problem based learning.

Ada 2 jenis intrumen yang akan

dibuat untuk mengumpulkan data dalam penelitian ini, yaitu:

1. Lembar Observasi

a. Lembar observasi keterlaksanaan proses pembelajaran menggunakan model PBL oleh guru yang berhubungan dengan bagaimana guru menjalankan setiap sintak sesuai dengan model PBL, yaitu orientasi peserta didik pada masalah, menggorganisasikan peserta didik untuk belajar, membimbing penyelidikan mandiri maupun kelompok, mengembangkan dan menyajikan hasil karya, menganalisis dan mengevaluasi proses pemecahan masalah.

b. Lembar observasi aktivitas peserta didik dalam proses pembelajaran yang berhubungan dengan tindakan yang dilakukan oleh peserta didik dalam proses pembelajaran dengan cara guru melaksanakan observasi,yaitu untuk melihat tindakan peserta didik baik bekerja secara individu ataupun berkelompok meliputi pembagian kerja dalam kelompok, setiap anggota kelompok bekerja sesuai dengan kelompoknya, informasi yang di dapat akurat sesuai dengan sumber belajar yang dipakai, dan lembar kerja peserta didik telah disusun dengan baik sesuai dengan prosedur LKPD.

c. Lembar observasi lingkungan belajar diperoleh melalui observasi yang dilakukan observer. Observasi ini dilakukan untuk memperoleh informasi berhubungan dengan interaksi antara guru dan peserta didik, diantaranya peserta didik bebas dari rasa takut terhadap guru, peserta didik diberi kepercayaan dalam melaksanakan kegiatan dan dilatih untuk bertanggung jawab terhadap tugas yang dikerjakan. Interaksi antara peserta didik dengan peserta didik diantaranya terjalin komunikasi diantara sesama peserta didik, bekerja sama dalam kelompok, dan saling menghargai antara sesama peserta didik. Interaksi antara peserta didik dengan lingkungan belajar diantaranya peserta didik merasa senang dan betah dalam pembelajaran, kelas memiliki penerangan dan pentilasi yang baik, penataan peralatan kelas yang rapi, serta kelas terasa sejuk.

d. Lembar Observasi Kemampuan Argumentasi diperoleh dari observasi yang dilakukan observer. Observasi ini dilakukan untuk memperoleh informasi yang berhubungan dengan kemampuan argumentasi peserta didik, diantaranya : 1) argumentasi berupa klaim sederhana atau klaim berlawanan, 2) argumentasi berupa claim yang disertai data, jaminan atau dukungan tetapi tidak mengandung sangahan, 3) argumentasi mengandung serangkaian klaim disertai data, jaminan atau dukungan dan sesekali sanggahan yang lemah, 4) argumentasi mengandung kalim disertai satu sanggahan yang dapat diidenfitikasi dengan jelas, tepat dan mengandung beberapa klaim, 5) yaitu argumentasinya luas namun tetap terkait dengan materi pembelajaran dengan lebih dari satu sanggahan yang jelas dan tepat.

\section{Dokumentasi}

Dokumentasi adalah metode untuk mengumpulkan data melalui penelusuran bukti fisik mengenai penelitian yang dilaksanakan dengan tujuan untuk mendokumentasikan kegiatan-kegiatan selama proses pembelajaran yang diperoleh melalui rekaman video. Metode rekaman video digunakan untuk mengamati semua aktivitas yang terjadi selama proses pembelajaran mengunakan model PBL. 


\section{$\pi$ (Phi)}

Karena dengan observasi mungkin saja ada hal-hal yang terlewati. Dengan adanya rekaman video dapat dilihat kembali proses pembelajaran yang telah dilaksanakan, sehingga dapat mengetahui dengan baik hal-hal apa saja yang terjadi selama proses pembelajaran berlangsung. Rekaman video akan memberikan informasi yang akurat tentang tindakan yang dilakukan dalam pembelajaran. Hasil rekaman video yang dibuat dapat penulis diskusikan dengan pembimbing tesis dan observer untuk memperoleh solusi dari masalah yang terjadi selama pembelajaran menggunakan model PBL.

Analisis data dilakukan setiap kali setelah pemberian suatu tindakan. Teknik analisis data yang digunakan dalam penelitian ini adalah mengunakan model menurut Miles dan Huberman dalam Sugiono (2013:337) menganalisis dalam tiga komponen yaitu sebagai berikut.

a. Reduksi Data (data reduction)

Reduksi data adalah bagian dari analisis yang diawali dengan proses menyeleksi, memilih, menyederhanakan data yang diperoleh. Peneliti menyeleksi data dengan memilih data yang sesuai dengan penelitian khususnya tujuan penelitian (Sugiyono, 2013:247). Data yang tidak relevan atau tidak lengkap dapat dihilangkan atau tidak perlu dianalisis. Reduksi data dilakukan sejak awal pengumpulan data kemudian menganalisis dan menyeleksi data yang digunakan dan data yang tidak digunakan dalam penelitian. Hal tersebut dilakukan untuk mendapatkan informasi yang akurat, sehingga peneliti dapat menarik kesimpulan untuk dipertanggungjawabkan.

b. Penyajian Data

Penyajian data adalah mengatur, menempatkan, dan merangkai seluruh informasi yang diperoleh kemudian dikemas dalam suatu penyajian. Penyajian data dilakukan dengan cara menyusun data yang telah direduksi sebelumnya dan menyajikannya dalam bentuk penjelasan deskripsi berupa teks naratif (Sugiyono, 2013:249). Selain dalam bentuk deskriptif teks naratif, data hasil penelitian juga akan disajikan dalam bentuk tabel, bagan, diagram, dan gambar untuk memudahkan dalam mebaca ringkasan hasil data. Data yang telah disajikan dibuat penafsiran dan evaluasi meliputi, 1. Pelaksanaan tindakan, 2. Perlunya perubahan tindakan, 3 . Alternatif tindakan yang dianggap tepat, 4 . Persepsi peneliti, guru, dan teman sejawat selaku observer pembelajaran, 5. Hambatan yang muncul dan alternatif penyelesaiannya.

c. Penarikan kesimpulan

Penarikan kesimpulan merupakan tahap akhir dari analisis data menurut Miles dan Hubberman (Sugiyono, 2013: 252). Penarikan kesimpulan berasal dari penafsiran makna data yang telah ditemukan. Langkah pada analisis data berupa reduksi data, penyajian data, dan penarikan kesimpulan mewakili serangkain penelitian yang telah dilakukan oleh peneliti. data yang telah dianalisis kemudian dijelaskan secara deskriptif untuk menjawab pertanyaan penelitian.

Interprestasi data merupakan proses memaknai data yang telah dikumpulkan dan dianalisis. menurut Arifah (2017:147) menagatakan bahwa interprestasi data adalah memberi arti terhadap hasil penelitian berdasarkan pemahaman yang dimiliki oleh peneliti. Hal senada juga dijelaskan oleh Creswell (2015:508) bahwa interprestasi data melibatkan pemahaman data. Selain itu, pada tahap interprestasi juga dilakukan upaya pengambilan hal-hal penting atau pelajaran yang bersumber dari hasil penelitian. Dalam penelitian kualitatif, interprestasi data juga diartikan sebagai langkah mundur oleh seorang peneliti dan pembentukan makna yang lebih besar tentang fenomena yang diteliti dan didasarkan pada pandangan pribadi, membandingkan hasil dengan penelitian terdahulu, atau kedua-duanya. 


\section{$\pi$ (Phi)}

Interprestasi data tidak luput dari perbandingan antara hasil penelitian dengan informasi yang diperoleh dari beberapa literatur. Creswell (2015:509) menjelaskan bahwa pada penelitian kualitatif pandangan pribadi merupakan hal yang tidak dapat dipisahkan dari tahap interprestasi. Oleh karena itu, refleksi pribadi tentang makna data sangat dibutuhkan.

Interprestasi data dapat juga berisi referensi kepustakaan dan hasil-hasil penelitian sebelumnya. Pada penelitian kualitatif, interprestasi data dilakukan dengan melihat hasil-hasil penelitian sebelumnya. Selanjutnya, peneliti menunjukkan bagaiman temuan penelitiannya mendukung atau justru bertentangan dengan hasil penelitian sebelumnya (Creswell, 2015:510). Dengan demikian, pada interprestasi data dilakukan pembandingan antara temuan yang diperoleh dengan pandangan dari teori-teori yang telah ada.

\section{HASIL DAN PEMBAHASAN}

Pada siklus I Parameter keterlaksanaan tindakan dalam proses pembelajaran menggunakan model problem based learning dengan penugasan LKPD berjalan dengan cukup baik, semua tahapan pembelajaran telah dilakukan, namun masih ada kekurangan dalam hal menyamapaikan nilai yang diperoleh setelah memperlajari meteri tentang konsep nilai mutlak linear satu variabel. Guru tidak memberikan contoh lay out LKPD. Peserta didik tidak mempunyai cukup waktu untuk menyelesaikan LKPD yang mereka buat. Parameter aktivitas peserta didik dalam menyelesaikan LKPD masih kesulitan dalam pengisian LKPD karena guru tidak memberikan contoh dan belum semua peserta didik membawa informasi untuk pengisian LKPD.

Parameter suasana lingkungan belajar yang yang aman, nyaman dan menyenangkan belum terlaksana dengan baik, masih ada beberapa kelompok yang belum dapat

bekerjasama dengan baik. Indikatorindikator kemampuan argumentasi matematika belum terlaksana dengan baik, karena sebaian besar kelompok yang tampil untuk presentasi masih membacakan LKPD mereka secara keseluruhan dan belum dapat menyampaikan dengan kata-katanya sendiri.

Pada siklus II parameter keterlaksanaan tindakan guru dalam proses pembelajaran Kegiatan pembelajaran berjalan dengan baik dan guru telah melaksanakan semua indikator-indikator kegiatan guru dalam proses pembelajaran. Parameter suasana lingkungan belajar yang seharusnya terjadi dalam proses pembelajaran masih terdapat indikator yang belum berjalan dengan baik, hal ini terlihat dari masih terdapat beberapa kelompok yang belum dapat bekerjasama dengan baik. sebagian besar indikator kemampuan argumentasi matematika peserta didik telah terlaksana dengan baik, namun masih ada beberapa indikator yang masih belum terlaksana dengan baik seperti indikator menyampaikan warrant, peserta didik masih menyampaikan warrant dengan katakata mereka sendiri tanpa didukung dengan data (backing).

Pada siklus III keterlaksanaan indikator-indikator tindakan guru dalam proses pembelajaran berjalan dengan baik dan guru telah melaksanakan semua indikator tersebut. Indikator-indikator aktivitas kegiatan peserta didik dalam penerapan model problem based learning telah terlaksanakan dengan baik.Indikatorindikator suasana lingkungan belajar yang seharusnya tercipta telah terlaksana dengan baik, hal ini tampak dari semua kelompok telah dapat bekerjasama dengan baik dengan sesama anggota kelompoknya. Indikator-indikator kemampuan argumentasi matematika peserta didik telah terpenuhi dengan baik, hal ini tampak dari peserta didik telah mampu menyampaikan argumennya sampai pada tahap backing. 


\section{PEMBAHASAN}

Penelitian tindakan kelas ini dilaksanakan pada semester ganjil, tepatnya pada tanggal 09 September sampai tanggal 11 Oktober 2019 tahun pelajaran 2019/2020. Penentuan waktu berdasarkan kalender akademik yang ada di SMA Negeri 2 Kota Jambi. Tempat penelitian adalah SMA Negeri 2 Kota Jambi yang beralamat Di Jalan Pangeran Antasari Kelurahan Talang Banjar Kecamatan Jambi Timur Kota Jambi. Subjek pada penelitian ini adalah peserta didik kelas X IPA 1 tahun pelajaran 2019/2020.

Sebelum melaksanakan penelitian siklus I, terlebih dahulu peneliti mencari data awal yaitu melakukan observasi secara langsung yang dilakukan peneliti pada proses pembelajaran dan dengan wawancara terhadap guru mata pelajaran matematika di SMAN 2 Kota Jambi, hal ini dilakukan karena peneliti merupakan salah satu guru yang mengajar di SMAN 2 Kota Jambi. Diketahui bahwa dalam proses pembelajaran masih berpusat pada guru. Guru kurang memperhatikan kemampuan argumentasi peserta didik. . Peserta didik juga tidak dibiasakan untuk memecahkan permasalahan dan menyampaikan pendapat mereka dalam proses pembelajaran.

PTK ini dilakukan sebanyak 3 siklus, yang mana masing-masing siklus 3 kali pertemuan dan tiap pertemuan memiliki alokasi waktu selama 2 x 45 menit. Pelaksanaan PTK dilakukan selama 5 minggu dan jadwal pertemuan sesuai dengan jadwal pelajaran Matematika di kelas tersebut. Dalam setiap siklusnya, PTK ini membahas materi pelajaran tentang "Persamaan dan pertidaksamaan Nilai Mutlak" yang merupakan kelanjutan dari materi selanjutnya. Pada siklus I dibahas tentang Nilai Mutlak Linear Satu Variabel yang dilaksanakan pada tanggal 11, 12, dan 17 September 2019. Proses pembelajaran dengan model problem based learning berjalan dengan cukup baik, semua tahapan pembelajaran telah dilakukan, namun masih ada kekurangan dalam hal menyamapaikan nilai yang diperoleh setelah memperlajari meteri tentang konsep nilai mutlak linear satu variabel. Guru tidak memberikan contoh lay out LKPD. Peserta didik tidak mempunyai cukup waktu untuk menyelesaikan LKPD yang mereka buat. Semua kelompok sudah membawa bahan pengisian LKPD, namun masih ada beberapa orang peserta didik dalam kelompok yang tidak membawa informasi/data yang diperlukan dalam pengisian LKPD mereka. sehingga pada proses pengisian LKPD peserta didik masih bingung dan banyak pertanyaan. Pada penilaian LKPD, 4 kelompok mendapat nilai baik dan 2 kelompok cukup baik. Lingkungan belajar yang aman mulai tercipta hanya saja masih ada peserta didik yang belum disiplin. Lingkungan yang nyaman belum tercipta karena belum terjadi komunikasi yang akrab antar peserta didik dalam kelompok, dan menyenangkan sudah tercipta hanya saja ada beberapa peserta didik yang belum menghargai waktu. Pada saat presentasi peserta didik masih membaca LKPD secara keseluruhan dan belum sepenuhnya memahami apa yang mereka buat dalam LKPD mereka. Dalam 6 aspek pengamatan kemampuan argumentasi peserta didik (claim data, warrant,backing, modal qualifier,dan rebuttal), beberapa orang peserta didik telah dapat menyampaikan claim data,dan warrant. Namun kelihatan peserta didik masih bingung dan belum memahami tahapan argumentasi dengan baik dan benar.

Siklus II yang dibahas materi tentang Sistem Persamaan Linear Tiga Variabel yang dilaksanakan pada tanggal 19, 26 September dan 01 Oktober 2019. Proses pembelajaran dengan model problem based learning berjalan dengan baik guru sudah melaksanakan semua tahapan pembelajaran dan memberikan contoh lay out LKPD. Semua kelompok sudah membawa bahan untuk pengisian LKPD. Jumlah peserta didik dan kualitas informasi /data yang di 


\section{$\pi$ (Phi)}

bawa lebih baik dari siklus I. Pada proses pengisian LKPD peserta didik telah mengerti karena guru sudah memberikan contoh lay out.Semua kelompok telah mencantumkan hasil diskusi pada LKPD . Pada LKPD 3 kelompok mendapat nilai sangat baik,dan 2 kelompok baik dan 1 kelompok cukup baik. Lingkungan belajar yang aman, nyaman, dan menyenangkan sudah tercipta . Semua descriptor lingkungan belajar yang aman, nyaman sudah muncul. Pada saat presentasi peserta didik sudah mampu menyampaikan LKPD dengan baik dan sudah tidak membaca keseluruhan disaat LKPD mereka. Dalam 6 aspek pengamatan kemampuan argumentasi peserta didik peserta didik (claim data, warrant, backing, modal qualifier,dan rebuttal ) , setelah peserta didik mendapatkan penjelasan tentang tahapan argumentasi, contoh argumentasi yang diberikan guru, dan pemberian waktu untuk menyiapkan diri untuk menyelesaikan media presentasi. Peserta didik telah dapat menyampaikan claim, data, warrant, dan backing (menyakinkan orang lain) dengan lebih baik.

Siklus III yang dibahas tentang pertidaksamaan Rasional, Irasional dan Sistem Persamaan Linear Tiga Variabel yang dilaksanakan pada tanggal 03, 08 dan 11 Oktober 2019. Proses pembelajaran dengan model problem based learning berjalan dengan sangat baik. Guru telah melaksanakan semua tahapan pembelajaran dengan kualitas yang lebih baik. Semua kelompok sudah membawa bahan pembuatan media presentasi. Jumlah peserta didik dan kualitas informasi /data yang di bawa lebih baik dari siklus II. Pada proses pembuatan media presentasi peserta didik dapat mengerjakan secara mandiri dan saling mengingatkan jika terjadi kesalahan, guru hanya memantau kegiatan peserta didik.Semua kelompok telah mencantumkan hasil diskusi pada media presentasi. Pada penilaian media presentasi 4 kelompok mendapat nilai sangat baik dan 2 kelompok mendapat nilai baik.
Lingkungan belajar yang aman, nyaman, dan menyenangkan sudah tercipta, semua deskriptor lingkungan belajar yang aman, nyaman, dan menyenangkan sudah muncul pada siklus III. Peserta didik sudah mamapu mempresentasikan hasil diskusi dengan baik tanpa membaca media presentasi. Dalam 6 aspek pengamatan argumentasi peserta didik (claim, data, warrant, backing, dan qualifier,dan rebuttal). Setelah mendapat penjelasan tentang tahapan argumentasi dari guru secara jelas dan peserta didik diminta untuk menuliskan pernyataan dibuku catatan, peserta didik sudah bisa memahami tahapan argumentasi dan berargumentasi dengan baik sampai tahapan backing (meyakinkan orang lain) sangat baik.

\section{SIMPULAN}

1. Perubahan Tindakan Guru antar Siklus

Pada siklus I guru dan peserta didik masih dalam tahap mencoba penggunaan model Problem Based Learning (PBL) sehingga perlu adanya tindakan perubahan pada siklus berikutnya. Guru memberikan banyak penjelasan dan pemahaman tentang model PBL. Pada siklus II guru tidak perlu lagi menjelaskan tentang tahapan model PBL kepada peserta didik karena meraka sudah memahami tentang tahapan model PBL dengan baik. Pada siklus III guru hanya mengarahkan peserta didik dalam proses pembelajaran menggunakan model PBL.

2. Perubahan aktivitas Peserta Didik antar Siklus

Pada siklus I peserta didik banyak mengajukan pertanyaan karena meraka belum memahami tentang proses pembelajaran dengan mengunakan model PBL. Pada siklus II peserta didik sudah memahami tentang tahapan model PBL sehingga guru tidak perlu lagi menjelaskan dan peserta didik sudah bisa melakukan tahapan PBL dengan baik. Pada siklus III peserta didik sudah secara mandiri melaksanakan proses atau tahapan 


\section{$\pi$ (Phi)}

pembelajaran model PBL dengan baik dan benar.

3. Lingkungan belajar

Lingkungan belajar di SMAN 2 Kota Jambi sudah mengalami perubahan dari siklus I sampai siklus III. Pada siklus I belum tercipta lingkungan belajar yang aman, nyaman, dan menyenangkan secara utuh, peserta didik masih terlihat ribu, komunikasi antar peserta didik dengan guru maupun antar peserta didik dengan peserta didik masih belum berjalan dengan baik, hal ini dikarenakan penerapan model PBL yang baru pertama kali dilaksanakan sehingga peserta didik masih memerlukan penjelasan dan pemahaman tentang tahapan model PBL. Pada siklus II dan siklus III suasana belajar yang aman, nyaman, dan menyenangkan sudah tercipta, hal ini ditandai dengan tidak terjadi lagi suasana ribut dalam skala besar dan komunikasi peserta didik dengan guru sudah berjalan dengan baik, komunikasi peserta didik dengan peserta didik juga sudah berjalan dengan baik, serta kerjasama antar peserta didik juga sudah tercipta dan suasana saling menghargai sudah muncul.

4. Kemampuan Argumentasi Peserta Didik

Kemampuan argumentasi peserta didik pada siklus I sudah terlihat baik. Hal ini dilihat dari beberapa peserta didik yang mampu menyampaikan tahapan argumentasi sampai pada tahap backing. Pada siklus II terlihat sudah lebih banyak peserta didik yang mampu menyampaikan argumentasi mereka sampai pada tahapan backing. Pada siklus III peserta didik sudah memahami tentang tahapan argumentasi dan peserta didik sudah semakin banyak yang menyampaikan argumentasinya dengan kualiatas yang lebih baik.

\section{DAFTAR PUSTAKA}

Abdullah, A.G dan Ridwan, T. (2008). Impelentasi Problem Based Learning (PBL) Pada Proses Pembelajaran di BPTP Bandung. [online]. Tersedia http://file.upi.edu/Direktori/FPTK/JU
R._PEND._TEKNIK_ELEKTRO.Pdf . Dipetik 30 Maret 2019.

Alzanina, A.E. (2016). Pengaruh Model Problem Based Learning terhadap Kemampuan Komunikasi Matematika Siswa. Skripsi Fakultas Keguruan dan Ilmu Pendidikan Universitas Lampung. Bandar Lampung

Aururrahman, (2012). Belajar dan Pembelajaran. Bandung: Alfabeta.

Arifah, F.N. (2017). Panduan Menulis Penelitian Tindakan Kelas \& Karya Ilmiah untuk Guru. Yogyakarta: Araska Publisher.

Aqib, Zainal. (2013). Model-Model, Media, Dan Strategi Pembelajaran Konstektual (Inovatif). Bandung: Yrama Widya.

Bambang, R. (2015). Pembelajaran Berbasis Masalah Untuk Meningkatkan Kemampuan Argumentasi Matematis Mahasiswa. Jurnal Ilmiah Program Studin Matematika STKIP Siliwangi Bandung, (4)2, 120 - 139.

Creswell, J. (2015). Riset Pendidikan: Perencanaan, Peleksanaan Edisi Kelima, dan Riset Kualitatif \& Kuantitatif. Terjemahan Soetjipto, H.P \& Soetjipto, S.M. Yogyakarta: Pustaka Belajar.

Dimyati dan Mudjiono. (2009). Belajar dan Pembelajaran. Jakarta: PT. Rineka Cipta.

Elliot, J. (1991). Action Research For Educational Change. Philadelphia : Open University Press.

Ekanara, Adisendjaja, dan Hamdiyati. (2018). Hubungan Kemampuan Penalaran Dengan Keterampilan Argumentasi Siswa Pada Konsep Sistem Pencernaan Melalui PBL. Jurnal Biologi dan Pembelajarannya, (13)2.

Ekanara, B., Yusuf, H., dan Yanti, H. (2015). Hubungan Kemampuan Penalaran Dengan Keterampilan Argumentasi Siswa Pada Konsep 


\section{$\pi$ (Phi)}

Sistem Pencernaan Melalui Pembelajaran Problem Based Learning. Jurnal Biologi dan Pembelajaran, (13), 2527-4562.

Fathurrohman, M. (2015). Model-Model Pembelajaran Inovatif. Yogyakarta: Kalimedia.

Gunantara, Suarjana, dan Riastini, M. (2014). Penerapan Model Pembelajaran Problem Based Learning Unruk Meningkatkan Kemampuan Pemecahan Masalah Matematika Siswa Kelas V. Jurnal Mimbar PGSD Universitas Ganesh, 2(1).

Handika, P. A. (2017). Pengaruh Skill Argumentasi mengunakan Model Pembelajaran Problem Based Learning (PBL) Terhadap Hasil Belajar Siswa SMP. Tidak diterbitkan. Universitas Lampung.

Harjali. (2019). Penataan Lingkungan Belajar: Strategi Untuk Guru dan Sekolah. Malang: Seribu Bintang.

Hosnan,M . (2014). Pensekatan Saintifik dan Kontektual dalam Pembelajaran Abad 21. Jakarta: Ghalia Indonesia.

Huda, M. (2014). Model - Model Pengajaran dan Pembelajaran. Yogyakarta: Pustaka Belajar.

Isro'atun dan Rosmala, Amelia. (2018). Model-Model Pembelajaran Matematika. Bandung: Bumi Aksara.

Istiyah dan Marwati. (2012). Media Pembelajaran. Jakarta: PT. Multi Kreasi Satudelapan.

Jayawardana. (2015). Pengaruh Penerapan Metode Guided Inquiiry Terhadapa Aktivitas dan Hasil Belajar Biologi Siswa Kelas X SMA N 2 Banguntapan. Jurnal Bioedukatika, (3), 2338-6630.

Jingga. (2013). Panduan Penyusunan Rencana Pelaksanaan Pembelajaran (RPP). Jakarta : Araska

Jonassen, D.H. (2004). Learning To Solve Problems : an Instructional Design Guide. San Fransisco: Pfeiffer.
Keraf, G. (2003). Argumentasi dan Narasi. Gramedia Pustaka Utama.

Mohamed. A., dan Kadir, F.A.A. (2013). Human Develovment : Study On Aspeccts Of Self Motivation to The Patient Dring Healing Process Through and Alternative Treatment. Internasional Jurnal of Human Development and Sustainnability.

Muhson, A. (2009). Peningkatan Minat Belajar dan Pemahaman Mahasiswa Melalui Penerapan Problem Based Learning. Jurnal Pendidikan, (39), 171-182

Mariyana, R. (2010). Pengelolaan Lingkungan Belajar. Jakarta. Kencana Media Grup.

Rusman (2013).

Model-Model Pembelajaran, Mengembangkan Fropesionalisme Guru. Jakarta: Rajawali Pers, PT. Rajagrafindo Persada.

Sanjaya, W. (2013). Strategi Pembelajaran Berorientasi Standar Proses Pendidikan. Jakarta. Kencana Prenada Media Grup.

Sinaga, B., Kristianto, A., Pardomuan, Lasker, P., dan Susianto. (2013). Buku Matematika Siswa Kelas X Kurikulum 2013. Balitbang: Kemdikbud.

Simon, Erduran, dan Osbrne. (2004). TaPping Into Argumentation Developments In The Application Of Taulmin' Argement Pattern For Studying Science Discourse. Science education. Online www.Interscience.wiley.com

Slavin, R. E. (2006). Psikologi Pendidikan Teori dan Praktik. Terjemahan oleh Marianto Samosir. Jakarta: PT Indeks. Sugiyono. (2013). Metode Penelitian Pendidikan: Pendekatan Kuantitatif, Kualitatif dan $R$ \& $D$. Bandung: Alfabeta.

Sukmawati, I., Neviyarni, Syukur, Y., dan Said, A. (2013). Peningkatan Hasil Belajar Melalui Dinamika Kelompok Dalam Perkuliahan Pengajaran 
Psikologi dan Bimbingan Konseling. Pedagogik. Jurnal Ilmiah Ilmu Pendidikan.

Sulhan, Najib. (2012). Manajemen Pembelajaran Guru Menuju Sekolah Efektif. Surabaya. Intelektual Club Surabaya.

Tim Penyusun. (2015). Pedoman Penulisan Tesis Program Magister Pendidikan Matematika Universitas Jambi, Jambi. Pascasarjana Universitas Jambi

Toulmin, S. (2003). The Uses Of Argument. New York: Cambridge University Press.

Toulmin, S. (2010). The Uses Of Argument. New York: Cambridge University Press.

Trianto. (2011). Model Pembelajaran IPA Terpadu. Jakarta : PT. Bumi Aksara

Uno, H.B dan Mohammad, N. (2014). Belajar dengan Pendekatan Pembelajaran Aktif, Inovatif, Lingkungan, Kreatif, Efektif, Menarik (PAILKEM). Jakarta: Bumi Aksara.

Vicent, J, Chick, H, dan McCrae. (2005). Argumentation Profile Charts Tool For Analysing Students Arguments. Melbourne: PME.281-288.

Widoyoko, E.P. (2016). Teknik Penyusunan Instrumen Penelitian. Yogyakarta: Pustaka Belajar.

Widyaningtyas, Sukarmin, dan Radiyono. (2013). Peran Lingkungan Belajar dan Kesiapan Belajar Terhadap Prestasi Belajar Fisika Siswa Kelas X SMAN 1 Pati. Jurnal Pendidikan Fisika, 1(1), 136-143.

Yamin, M. (2013). Paradikm

Pembelajaran. Jakarta : Referens 